\title{
New studies, technology, and the progress of epidemiology
}

\author{
Albert Hofman
}

Published online: 11 December 2010

(C) The Author(s) 2010. This article is published with open access at Springerlink.com

The progress of epidemiology depends on advances in epidemiologic methods and in research findings. For both, new technologies are highly important. It is, for example, difficult to understand the strong growth in epidemiologic data-analysis without the emergence of the computer, or of molecular and genetic epidemiology without major advances in molecular technology. The purpose of this editorial is to invite articles on the new technologies that are likely to play a crucial role in the further development of epidemiology and of epidemiologic research.

For the practice of epidemiology and its methods, we already see the first glimpses of introduction of modern information technology [1-9]. We have witnessed the application of new technology in the remarkable explosion of genome-wide association studies (GWAs) of various diseases [10-27] and traits [28-39]. We also see the first results of new imaging studies and the emergence of the exceedingly important field of population imaging [26, 40-47].

The new array technologies used in GWAs have led to interesting changes in the way epidemiologic research is conceived and performed. The "hypothesis free" approach in the GWAs, i.e. approach without use of prior knowledge, has been considerably more productive than the candidate gene approach. This is sobering for those of us who have an optimistic view on what we know, and has led to the boutade that "most recent findings are false" [48]. The GWAs have also led to large-scale collaborations in epidemiology in a form and quantity that we had not witnessed before, although it remains to be seen whether this is a lasting phenomenon [10, 49].

\footnotetext{
A. Hofman $(\bowtie)$

Department of Epidemiology, Erasmus Medical Center, PO Box 2040, 30000 CA Rotterdam, The Netherlands

e-mail: a.hofman@erasmusmc.nl
}

The new imaging techniques that are currently applied in population studies are likely to be the beginning of an avalanche in epidemiologic studies of many diseases. These imaging techniques enable epidemiologists to study disease at an earlier stage than when a clinical diagnosis can be made, allow for objective assessment of the disease or trait, and make repeated assessment possible. These features are likely to be very advantageous, in particular for etiologic epidemiologic research [50-78].

The European Journal of Epidemiology publishes quite frequently descriptions of new studies and presents also occasionally updates of these studies' objectives and design [3, 40, 41, 79-89]. We invite in particular new studies that make use of new technologies and we will also certainly consider manuscripts on the technical details of these technologies that are applied in epidemiologic research [90-92].

Open Access This article is distributed under the terms of the Creative Commons Attribution Noncommercial License which permits any noncommercial use, distribution, and reproduction in any medium, provided the original author(s) and source are credited.

\section{References}

1. Bexelius C, Merk H, Sandin S, Ekman A, Nyrén O, KühlmannBerenzon S, Linde A, Litton JE. SMS versus telephone interviews for epidemiological data collection: feasibility study estimating influenza vaccination coverage in the Swedish population. Eur J Epidemiol. 2009;24(2):73-81. (Epub 2008 Dec 10).

2. Ludvigsson JF, Otterblad-Olausson P, Pettersson BU, Ekbom A. The Swedish personal identity number: possibilities and pitfalls in healthcare and medical research. Eur J Epidemiol. 2009;24(11): 659-67. (Epub 2009 Jun 6).

3. Stolk RP, Rosmalen JGM, Postma DS, et al. Universal risk factors for multifactorial diseases-lifelines: a three-generation population-based study. Eur J Epidemiol. 2008;23(1):67-74. 
4. Stang A. Appropriate epidemiologic methods as a prerequisite for valid study results. Eur J Epidemiol. 2008;23(12):761-5.

5. Stolk RP, Hutter I, Wittek RP. Population ageing research: a family of disciplines. Eur J Epidemiol. 2009;24(11):715-8. (Epub 2009 Oct 28)

6. Alpérovitch A, Bertrand M, Jougla E, Vidal JS, Ducimetière P, Helmer C, Ritchie K, Pavillon G, Tzourio C. Do we really know the cause of death of the very old? Comparison between official mortality statistics and cohort study classification. Eur J Epidemiol. 2009;24(11):669-75. (Epub 2009 Sep 1).

7. Nur U, Longford NT, Cade JE, Greenwood DC. The impact of handling missing data on alcohol consumption estimates in the UK women cohort study. Eur J Epidemiol. 2009;24(10):589-95.

8. Schlaefer K, Schlehofer B, Schüz J. Validity of self-reported occupational noise exposure. Eur J Epidemiol. 2009;24(8): 469-75. (Epub 2009 Jun 19).

9. Graff-Iversen S, Anderssen SA, Holme IM, et al. Two short questionnaires on leisure-time physical activity compared with serum lipids, anthropometric measurements and aerobic power in a suburban population from Oslo, Norway. Eur J Epidemiol. 2008;23(3):167-74.

10. Psaty BM, Hofman A. Genome-wide association studies and large-scale collaborations in epidemiology. Eur J Epidemiol. 2010;25:525-9.

11. Danesh J, Hingorani A, Wensley F, et al. Collaborative pooled analysis of data on C-reactive protein gene variants and coronary disease: judging causality by Mendelian randomisation. Eur $\mathbf{J}$ Epidemiol. 2008;23(8):531-40.

12. Janssens ACJW. Is it the time right for translation research in genomics? Eur J Epidemiol. 2008;23(11):707-10.

13. Amin N, van Duijn CM, Janssens AC. Genetic scoring analysis: a way forward in genome wide association studies? Eur J Epidemiol. 2009;24(10):585-7.

14. van Wieren-de Wijer DB, Maitland-van der Zee AH, de Boer A, Belitser SV, Kroon AA, de Leeuw PW, Schiffers P, Janssen RG, van Duijn CM, Stricker BH, Klungel OH. Determinants of DNA yield and purity collected with buccal cell samples. Eur J Epidemiol. 2009;24(11):677-82. (Epub 2009 Sep 17).

15. Raoult D. Recent and future developments in the epidemiology of the infectious diseases. Eur J Epidemiol. 2009;24(8):393-5. (Epub 2009 Jun 16).

16. Mao RF, Fan YH, Chen F, et al. Genetic polymorphism of MTHFR G1793A in Chinese populations. Eur J Epidemiol. 2008;23(5):363-8.

17. Lei L, Ye LN, Liu H, et al. Passive smoking, cytochrome P450 gene polymorphisms and dysmenorrhea. Eur J Epidemiol. 2008; 23(7):475-81.

18. Osler M, Lund R, Kriegbaum M, Andersen AM. The influence of birth weight and body mass in early adulthood on early coronary heart disease risk among Danish men born in 1953. Eur J Epidemiol. 2009;24(1):57-61. (Epub 2008 Nov 21).

19. Manda SO, Feltbower RG, Gilthorpe MS. Investigating spatiotemporal similarities in the epidemiology of childhood leukaemia and diabetes. Eur J Epidemiol. 2009;24(12):743-52. (Epub 2009 Sep 26)

20. Nguyen QM, Srinivasan SR, Xu JH, Chen W, Berenson GS. Influence of childhood parental history of type 2 diabetes on the pre-diabetic and diabetic status in adulthood: the Bogalusa Heart Study. Eur J Epidemiol. 2009;24(9):537-9. (Epub 2009 Jul 19).

21. Fallah N, Mohammad K, Nourijelyani K, Eshraghian MR, Seyyedsalehi SA, Raiessi M, Rahmani M, Goodarzi HR, Darvish S, Zeraati H, Davoodi G, Sadeghian S. Nonlinear association between serum testosterone levels and coronary artery disease in Iranian men. Eur J Epidemiol. 2009;24(6):297-306. (Epub 2009 Apr 9).

22. Mayer O Jr, Simon J, Plásková M, Cífková R, Trefil L. N-terminal pro B-type natriuretic peptide as prognostic marker for mortality in coronary patients without clinically manifest heart failure. Eur J Epidemiol. 2009;24(7):363-8. (Epub 2009 Apr 9).

23. Hedlund E, Pehrsson K, Lange A, et al. Country of birth and survival after a first myocardial infarction in Stockholm, Sweden. Eur J Epidemiol. 2008;23(5):341-7.

24. Prugger C, Wellmann J, Heidrich J, et al. Cardiovascular risk factors and mortality in patients with coronary heart disease. Eur J Epidemiol. 2008;23(11):731-7.

25. de Luise C, Brimacombe M, Pedersen L, et al. Chronic obstructive pulmonary disease and mortality following hip fracture: a population-based cohort study. Eur J Epidemiol. 2008;23(2):115-22.

26. Hofman A. Recent trends in cardiovascular epidemiology. Eur $\mathbf{J}$ Epidemiol. 2009;24(12):721-3.

27. Thelle DS. The dynamics of cardiovascular epidemiology. Eur J Epidemiol. 2009;24(12):725-6. (Epub 2009 Dec 5. No abstract available).

28. Lagerros YT, Bellocco R, Adami HO, Nyrén O. Measures of physical activity and their correlates: the Swedish National March Cohort. Eur J Epidemiol. 2009;24(4):161-9. (Epub 2009 Mar 18).

29. Corpeleijn E, Bakker SJ, Stolk RP. Obesity and impaired renal function: potential for lifestyle intervention? Eur J Epidemiol. 2009;24(6):275-80. (Epub 2009 May 7).

30. Dörr M, Wallaschofski H, Friedrich N. Association of low total testosterone levels and prevalent carotid plaques: result of the study of health in Pomerania. Eur J Epidemiol. 2009;24(7):389-91. (Epub 2009 Jun 5).

31. Vikan T, Johnsen SH, Schirmer H, Njølstad I, Svartberg J. Endogenous testosterone and the prospective association with carotid atherosclerosis in men: the Troms $\varnothing$ study. Eur J Epidemiol. 2009;24(6):289-95. (Epub 2009 Mar 5).

32. Gemes K, Ahnve S, Janszky I. Inflammation a possible link between economical stress and coronary heart disease. Eur J Epidemiol. 2008;23(2):95-103.

33. Kompauer I, Demmelmair H, Koletzko B, et al. Association of fatty acids in serum phospholipids with lung function and bronchial hyperresponsiveness in adults. Eur J Epidemiol. 2008;23(3): 175-90.

34. Andreotti G, Menashe I, Chen J, Chang SC, Rashid A, Gao YT, Han TQ, Sakoda LC, Chanock S, Rosenberg PS, Hsing AW. Genetic determinants of serum lipid levels in Chinese subjects: a population-based study in Shanghai, China. Eur J Epidemiol. 2009;24(12):763-74. (Epub 2009 Nov 4).

35. Pearce MS, Relton CL, Parker L, Unwin NC. Sex differences in the association between infant feeding and blood cholesterol in later life: the Newcastle thousand families cohort study at age 49-51 years. Eur J Epidemiol. 2009;24(7):375-80. (Epub 2009 May 29).

36. Ruan L, Chen W, Srinivasan SR, Xu J, Toprak A, Berenson GS. Plasma homocysteine is adversely associated with glomerular filtration rate in asymptomatic black and white young adults: the Bogalusa heart study. Eur J Epidemiol. 2009;24(6):315-9. (Epub 2009 Apr 25).

37. Jacobi D, Charles MA, Tafflet M, Lommez A, Borys JM, Oppert JM. Relationships of self-reported physical activity domains with accelerometry recordings in French adults. Eur $\mathrm{J}$ Epidemiol. 2009;24(4):171-9. (Epub 2009 Mar 13).

38. Dragano N, Hoffmann B, Stang A, Moebus S, Verde PE, Weyers S, Möhlenkamp S, Schmermund A, Mann K, Jöckel KH, Erbel R, Siegrist J, Group HeinzNixdorfRecallStudyInvestigative. Subclinical coronary atherosclerosis and neighbourhood deprivation in an urban region. Eur J Epidemiol. 2009;24(1):25-35. (Epub 2008 Oct 18).

39. Bruyere O, Varela AR, Adami S, Detilleux J, Rabenda V, Hiligsmann M, Reginster JY. Loss of hip bone mineral density over time is associated with spine and hip fracture incidence in osteoporotic 
postmenopausal women. Eur J Epidemiol. 2009;24(11): 707-12. (Epub 2009 Aug 29).

40. Hofman A, Breteler MM, van Duijn CM, Janssen HL, Krestin GP, Kuipers EJ, Stricker BH, Tiemeier H, Uitterlinden AG, Vingerling JR, Witteman JC. The Rotterdam Study: 2010 objectives and design update. Eur J Epidemiol. 2009;24:553-72.

41. Kim BM, Ha M, Park HS, Lee BE, Kim YJ, Hong YC, Kim Y, Chang N, Roh YM, Kim BN, Oh SY, Ha EH MOCEH, Group Study. The Mothers and Children's Environmental Health (MOCEH) study. Eur J Epidemiol. 2009;24(9):573-83. (Epub $2009 \mathrm{Jul} 24)$.

42. Holzhauer S, Zwijsen RM, Jaddoe VW, Boehm G, Moll HA, Mulder PG, Kleyburg-Linkers VA, Hofman A, Witteman JC. Sonographic assessment of abdominal fat distribution in infancy. Eur J Epidemiol. 2009;24(9):521-9. (Epub 2009 Jul 29).

43. Forsen L, Berntsen GKR, Meyer HE, et al. Differences in precision in bone mineral density measured by SXA and DXA: the NOREPOS study. Eur J Epidemiol. 2008;23(9):615-24.

44. Ganry O, Lapotre-Ledoux B, Fardellone P, et al. Bone mass density, subsequent risk of colon cancer and survival in postmenopausal women. Eur J Epidemiol. 2008;23(7):467-73.

45. Ahmed LA, Schirmer H, Bjørnerem A, Emaus N, Jørgensen L, Størmer J, Joakimsen RM. The gender- and age-specific 10-year and lifetime absolute fracture risk in Tromsø, Norway. Eur J Epidemiol. 2009;24(8):441-8. (Epub 2009 May 30).

46. Emaus N, Omsland TK, Ahmed LA, Grimnes G, Sneve M, Berntsen GK. Bone mineral density at the hip in Norwegian women and men-prevalence of osteoporosis depends on chosen references: the Troms $\varnothing$ study. Eur J Epidemiol. 2009;24(6): 321-8. (Epub 2009 Mar 19).

47. Moayyeri A, Kaptoge S, Luben RN, Wareham NJ, Bingham S, Reeve J, Khaw KT. Estimation of absolute fracture risk among middle-aged and older men and women: the EPIC-Norfolk population cohort study. Eur J Epidemiol. 2009;24(5):259-66. (Epub 2009 Apr 7).

48. Loannidis JP. Why most published research findings are false. Plos Med. 2005;2:e124.

49. Thompson A. Thinking big: large-scale collaborative research in observational epidemiology. Eur J Epidemiol. 2009;24(12): 727-31. (Epub 2009 Dec 5. Review).

50. Pekkanen J, Sunyer J. Problems in using incidence to analyze risk factors in follow-up studies. Eur J Epidemiol. 2008;23(9):581-4.

51. Vaux S, Poujol I, Bonmarin I, Lévy-Bruhl D, Desenclos JC. Surveillance of lower respiratory tract infections outbreaks in nursing homes in France. Eur J Epidemiol. 2009;24(3):149-55. (Epub 2009 Feb 7).

52. Gulsvik AK, Thelle DS, Mowé M, Wyller TB. Increased mortality in the slim elderly: a 42 years follow-up study in a general population. Eur J Epidemiol. 2009;24(11):683-90. (Epub 2009 Sep 2).

53. Khashan AS, Kenny LC. The effects of maternal body mass index on pregnancy outcome. Eur J Epidemiol. 2009;24(11):697-705. (Epub 2009 Aug 4).

54. Setia MS, Quesnel-Vallee A, Abrahamowicz M, Tousignant P, Lynch J. Convergence of body mass index of immigrants to the Canadian-born population: evidence from the National Population Health Survey (1994-2006). Eur J Epidemiol. 2009;24(10): 611-23. (Epub 2009 Jul 30).

55. Bloch F, Jegou D, Dhainaut JF, Rigaud AS, Coste J, Lundy JE, Claessens YE. Can metabolic abnormalities after a fall predict short term mortality in elderly patients? Eur J Epidemiol. 2009;24(7):357-62. (Epub 2009 May 7).

56. Aarts S, van den Akker M, van Boxtel MP, Jolles J, Winkens B, Metsemakers JF. Diabetes mellitus type II as a risk factor for depression: a lower than expected risk in a general practice setting. Eur J Epidemiol. 2009;24(10):641-8.
57. Pires de Sousa AG, Pereira AC, Marquezine GF, NascimentoNeto RM, Freitas SN, Nicolato RLC, Machado-Coelho GL, Rodrigues SL, Mill JG, Krieger JE. Derivation and external validation of a simple prediction model for the diagnosis of type 2 diabetes mellitus in the Brazilian urban population. Eur J Epidemiol. 2009;24(2):101-9. (Epub 2009 Feb 4).

58. Laszlo KD, Janszky I, Ahnve S. Income and recurrent events after a coronary event in women. Eur J Epidemiol. 2008;23(10): 669-80.

59. Reuser M, Bonneux L, Willekens F. The burden of mortality of obesity at middle and old age is small. A life table analysis of the US Health and Retirement Survey. Eur J Epidemiol. 2008;23(9): 601-7.

60. McFadden E, Luben R, Wareham N, et al. Occupational social class, risk factors and cardiovascular disease incidence in men and women: a prospective study in the European prospective investigation of cancer and nutrition in Norfolk (EPIC-Norfolk) cohort. Eur J Epidemiol. 2008;23(7):449-58.

61. Zatonski W, Campos H, Willett W. Rapid declines in coronary heart disease mortality in Eastern Europe are associated with increased consumption of oils rich in alpha-linolenic acid. Eur $\mathbf{J}$ Epidemiol. 2008;23(1):3-10.

62. Spencer EA, Pirie KL, Stevens RJ, et al. Diabetes and modifiable risk factors for cardiovascular disease: the prospective Million Women Study. Eur J Epidemiol. 2008;23(12):793-9.

63. Duijts L, Jaddoe VWV, Hofman A, et al. Maternal smoking in prenatal and early postnatal life and the risk of respiratory tract infections in infancy. The generation R study. Eur J Epidemiol. 2008;23(8):547-55.

64. Lawlor DA, Cooper AR, Bain C, et al. Associations of birth size and duration of breast feeding with cardiorespiratory fitness in childhood: findings from the Avon longitudinal study of parents and children (ALSPAC). Eur J Epidemiol. 2008;23(6): 411-22.

65. Hugg T, Ruotsalainen R, Jaakkola MS, et al. Comparison of allergic diseases, symptoms and respiratory infections between Finnish and Russian school children. Eur J Epidemiol. 2008; 23(2):123-33.

66. Rzehak P, Schoefer Y, Wichmann HE, et al. A prospective study on the association between hay fever among children and incidence of asthma in East Germany. Eur J Epidemiol. 2008;23(1): $17-22$.

67. Wiesbauer F, Blessberger H, Goliasch G, Holy EW, Pfaffenberger S, Tentzeris I, Maurer G, Huber K, Abdolvahab F, Sodeck G, Exner M, Wojta J, Schillinger M. Elevated risk of myocardial infarction in very young immigrants from former Yugoslavia. Eur J Epidemiol. 2009;24(11):691-6. (Epub 2009 Sep 26).

68. Regidor E, Astasio P, Calle ME, Martínez D, Ortega P, Domínguez $\mathrm{V}$. The association between birthplace in different regions of the world and cardiovascular mortality among residents of Spain. Eur J Epidemiol. 2009;24(9):503-12. (Epub 2009 Jun 26).

69. Oliveira A, Barros H, Azevedo A, Bastos J, Lopes C. Impact of risk factors for non-fatal acute myocardial infarction. Eur J Epidemiol. 2009;24(8):425-32. (Epub 2009 Jun 4).

70. Merry AH, Boer JM, Schouten LJ, Feskens EJ, Verschuren WM, Gorgels AP, van den Brandt PA. Validity of coronary heart diseases and heart failure based on hospital discharge and mortality data in the Netherlands using the cardiovascular registry Maastricht cohort study. Eur J Epidemiol. 2009;24(5):237-47. (Epub 2009 Apr 1).

71. Jaffe DH, Neumark YD, Eisenbach Z, Manor O. Parity-related mortality: shape of association among middle-aged and elderly men and women. Eur J Epidemiol. 2009;24(1):9-16. (Epub 2009 Jan 13).

72. Turin TC, Kita Y, Rumana N, Sugihara H, Morita Y, Tomioka N, Okayama A, Nakamura Y, Ueshima H. Incidence, admission and 
case-fatality of acute myocardial infarction: weekend versus weekday in a Japanese population: 16-year results from Takashima AMI Registry (1988-2003). Eur J Epidemiol. 2009;24(2):93-100. (Epub 2008 Dec 17).

73. Schmassmann A, Oldendorf MG, Gebbers JO. Changing incidence of gastric and oesophageal cancer subtypes in central Switzerland between 1982 and 2007. Eur J Epidemiol. 2009;24(10):603-9. (Epub 2009 Aug 9).

74. Asfeldt AM, Steigen SE, Løchen ML, Straume B, Johnsen R, Bernersen B, Florholmen J, Paulssen EJ. The natural course of Helicobacter pylori infection on endoscopic findings in a population during 17 years of follow-up: the Sørreisa gastrointestinal disorder study. Eur J Epidemiol. 2009;24(10):649-58. (Epub $2009 \mathrm{Jul} 21)$.

75. Watanabe H, Kamijima Y, Sato T, Kaufman DW, Kubota K. Exdrinking may be a surrogate for unmeasured risk factors for upper gastrointestinal bleeding: reappraisal and an additional survey of subjects from a case-control study in Japan. Eur J Epidemiol. 2009;24(3):143-7. (Epub 2009 Feb 11).

76. Pisa FE, Verriello L, Deroma L, Drigo D, Bergonzi P, Gigli GL, Barbone F. The accuracy of discharge diagnosis coding for Amyotrophic Lateral Sclerosis in a large teaching hospital. Eur J Epidemiol. 2009;24(10):635-40. (Epub 2009 Aug 6).

77. Ahlgren C, Torén K, Odén A, Andersen O. A population-based case-control study on viral infections and vaccinations and subsequent multiple sclerosis risk. Eur J Epidemiol. 2009;24(9): 541-52. (Epub 2009 Jul 26).

78. Sylliaas H, Idland G, Sandvik L, Forsen L, Bergland A. Does mortality of the aged increase with the number of falls? Results from a nine-year follow-up study. Eur J Epidemiol. 2009;24(7): 351-5. (Epub 2009 May 19).

79. Jaddoe VWV, van Duijn CM, van der Heijden AJ, et al. The Generation R Study: design and cohort update until the age of 4 years. Eur J Epidemiol. 2008;23(12):801-11.

80. Saleheen D, Zaidi M, Rasheed A, Ahmad U, Hakeem A, Murtaza M, Kayani W, Faruqui A, Kundi A, Zaman KS, Yaqoob Z, Cheema LA, Samad A, Rasheed SZ, Mallick NH, Azhar M, Jooma R, Gardezi AR, Memon N, Ghaffar A, Fazal-ur-Rehman KhanN, Shah N, Ali Shah A, Samuel M, Hanif F, Yameen M, Naz S, Sultana A, Nazir A, Raza S, Shazad M, Nasim S, Javed MA, Ali SS, Jafree M, Nisar MI, Daood MS, Hussain A, Sarwar N, Kamal A, Deloukas P, Ishaq M, Frossard P, Danesh J. The Pakistan Risk of Myocardial Infarction Study: a resource for the study of genetic, lifestyle and other determinants of myocardial infarction in South Asia. Eur J Epidemiol. 2009;24(6):329-38. (Epub 2009 Apr 30).

81. Olafsdottir E, Aspelund T, Sigurdsson G, Thorsson B, Benediktsson R, Harris TB, Launer LJ, Eiriksdottir G, Gudnason V. Unfavourable risk factors for type 2 diabetes mellitus are already apparent more than a decade before onset in a population-based study of older persons: from the Age, Gene/Environment
Susceptibility-Reykjavik Study (AGES-Reykjavik). Eur J Epidemiol. 2009;24(6):307-14. (Epub 2009 May 2).

82. Heidemann $\mathrm{C}$, Boeing $\mathrm{H}$, Pischon $\mathrm{T}$, Nöthlings $\mathrm{U}$, Joost HG, Schulze MB. Association of a diabetes risk score with risk of myocardial infarction, stroke, specific types of cancer, and mortality: a prospective study in the European Prospective Investigation into Cancer and Nutrition (EPIC)-Potsdam cohort. Eur J Epidemiol. 2009;24(6):281-8. (Epub 2009 Apr 9).

83. Tasevska-Dinevska G, Kennedy LM, Nilsson PM, Willenheimer R. Gender aspects on heart failure incidence and mortality in a middle-aged, urban, community-based population sample: the Malmö preventive project. Eur J Epidemiol. 2009;24(5):249-57. (Epub 2009 Mar 8).

84. Greiser KH, Kluttig A, Schumann B, Swenne CA, Kors JA, Kuss O, Haerting J, Schmidt H, Thiery J, Werdan K. Cardiovascular diseases, risk factors and short-term heart rate variability in an elderly general population: the CARLA study 2002-2006. Eur J Epidemiol. 2009;24(3):123-42. (Epub 2009 Feb 7).

85. Berg-Beckhoff G, Schüz J, Blettner M, Münster E, Schlaefer K, Wahrendorf J, Schlehofer B. History of allergic disease and epilepsy and risk of glioma and meningioma (INTERPHONE study group, Germany). Eur J Epidemiol. 2009;24(8):433-40. (Epub 2009 May 31).

86. Larrieu S, Carcaillon L, Lefranc A, et al. Factors associated with morbidity during the 2003 heat wave in two population-based cohorts of elderly subjects: PAQUID and three city. Eur J Epidemiol. 2008;23(4):295-302.

87. McFadden E, Luben R, Wareham N, Bingham S, Khaw KT. How far can we explain the social class differential in respiratory function? A cross-sectional population study of 21, 991 men and women from EPIC-Norfolk. Eur J Epidemiol. 2009;24(4): 193-201. (Epub 2009 Mar 14).

88. Rzehak P, Sausenthaler S, Koletzko S, Bauer CP, Schaaf B, von Berg A, Berdel D, Borte M, Herbarth O, Krämer U, Fenske N, Wichmann HE, Heinrich J. Period-specific growth, overweight and modification by breastfeeding in the GINI and LISA birth cohorts up to age 6 years. Eur J Epidemiol. 2009;24(8):449-67. (Epub 2009 Jun 12).

89. Balk L, Hoekstra T, Twisk J. Relationship between long-term coffee consumption and components of the metabolic syndrome: the Amsterdam Growth and Health Longitudinal Study. Eur J Epidemiol. 2009;24(4):203-9. (Epub 2009 Mar 10).

90. Little J, Higgins JP, Moher D, Gagnon F, von Elm E, et al. Strengthening the reporting of genetic association studies (STREGA): an extension of the STROBE statement. Eur J Epidemiol. 2009;24(1):1-5.

91. Miettinen OS. Up from 'false positives' in genetic-and other epidemiology. Eur J Epidemiol. 2009;24(1):1-5.

92. Thelle DS. STROBE and STREGA: instruments for improving transparency and quality of reporting scientific results. Eur $\mathbf{J}$ Epidemiol. 2009;24(1):7-8. 